\title{
Cafeteria diet intake for fourteen weeks can cause obesity and insulin resistance in Wistar rats
}

\author{
Dieta de cafeteria por quatorze semanas \\ pode causar obesidade e resistência \\ insulínica em ratos Wistar
}

Danilo Antônio Corrêa PINTO JÚNIOR'

Patricia Monteiro SERAPHIM ${ }^{1}$

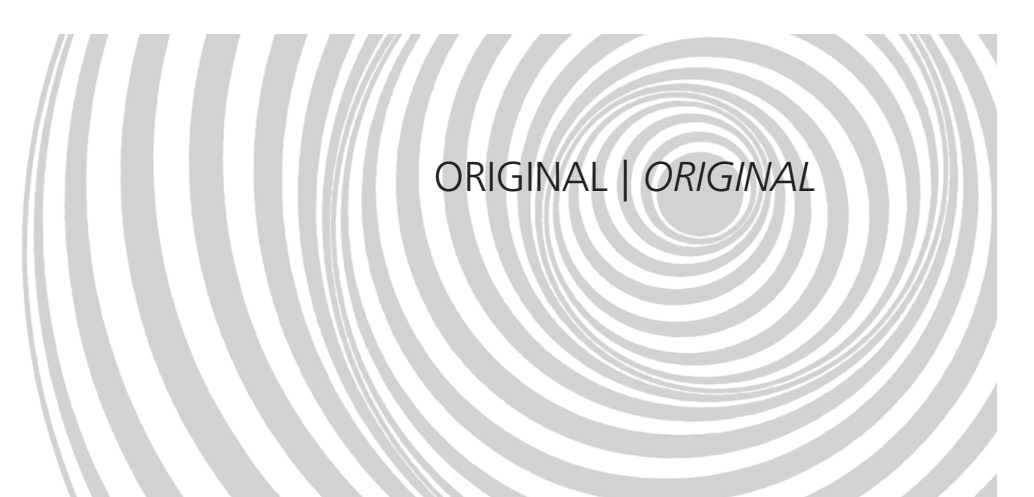

A B S T R A C T

\section{Objective}

Obesity is a strong predictor of some kinds of diseases. High intake of high-fat foods contributes significantly to the growth of the obese population globally. The aim of this study was to verify if consumption of a cafeteria diet for fourteen weeks could increase white fat mass, body weight and skeletal muscle mass and promote insulin resistance in male Wistar rats.

\section{Methods}

Twenty animals were divided into two groups: control and obese. Both were fed standard chow and water ad libitum. Additionally, a cafeteria diet consisting of bacon, bologna sausage, sandwich cookies and soft drink was given to the obese group.

\section{Results}

The obese group was significantly heavier $(p<0.0001)$ than controls from the second week until the end of the cafeteria-diet intervention. Absolute and relative fat mass, liver weight and Lee Index increased significantly $(p<0.05)$ in the obese group. Furthermore, the obese group had lower $(p<0.05)$ insulin sensitivity than the control group.

\section{Conclusion}

In conclusion, fourteen weeks of cafeteria diet promoted a progressive increase of fat mass and insulin resistance. Therefore, this is a great and inexpensive diet-induced insulin resistance model.

Indexing terms: Cafeteria diet. High-fat food. Insulin resistance. Obesity.

\footnotetext{
1 Universidade Estadual Paulista Júlio de Mesquita Filho, Faculdade de Ciências e Tecnologia de Presidente Prudente. R. Roberto Simonsen, 305, 19060-900, Presidente Prudente, SP, Brasil. Correspondência para/Correspondence to: DAC PINTO JÚNIOR. E-mail:<patricia@fct.unesp.br>.
} 
314 DAC PINTO JÚNIOR \& PM SERAPHIM

\section{RE S U M O}

\section{Objetivo}

A obesidade é um forte preditor de alguns tipos de doenças. A grande oferta de comida e a predominância de ácidos graxos presentes na maioria dos alimentos contribuem diretamente para o aumento da população obesa no mundo. O objetivo do estudo foi verificar se uma dieta de cafeteria durante um período de catorze semanas pode causar aumento dos pesos de tecido adiposo branco, corporal e muscular e provocar um quadro de resistência insulínica em ratos machos Wistar.

\section{Métodos}

Vinte ratos machos Wistar foram divididos em dois grupos: controle e obeso. Os dois grupos foram alimentados com ração padrão e água ad libitum. Ao grupo obeso foi ofertada dieta ocidental, composta por salsicha, mortadela, bolacha recheada, bacon e refrigerante.

\section{Resultados}

Os animais do grupo obeso estavam significantemente mais pesados a partir da segunda semana de tratamento e essa diferença permaneceu até o final do estudo $(p<0,0001)$. O peso absoluto e relativo do tecido adiposo branco e do fígado, e o Índice de Lee foram maiores no grupo obeso $(p<0,05)$, que apresentou uma menor sensibilidade à insulina no final do estudo quando comparado ao grupo controle $(p<0,05)$. Podemos observar que a dieta cafeteria promoveu um aumento progressivo e significativo da massa de gordura corporal associada à disfunção da ação da insulina.

\section{Conclusão}

Conclui-se que uma dieta de cafeteria por um período de catorze semanas é capaz de promover aumento progressivo da massa adiposa associada à disfunção da insulina, sendo ótimo e fácil modelo de para induzir resistência à insulina.

Termos de indexação: Dieta de cafeteria. Alimento hipercalórico. Resistência à insulina. Obesidade.

\section{INTRODUCTION}

Obesity is generally associated with high food intake (junk food) and many diseases. According to the World Health Organization $(\mathrm{WHO})$, there are 1.5 billion adults with excess weight in the world, of which 200 million are obese. This metabolic state affects increasingly younger people. Roughly, 22 million children under 5 years of age are overweight ${ }^{1}$.

Obesity is multifactorial and the causes may be genetic, environmental, metabolic and/ or behavioral².

Today, because of the high fat content in foods, obesity does not affect only individuals in developed countries, but also those in developing countries. Bad quality food and the ease of making high-fat foods further contribute to the increase in the number of obese individuals worldwide. Pan et al. ${ }^{3}$ followed 3 cohorts (about 200,000 people) and found that people who eat red meat are more likely to develop Type- 2
Diabetes (T2D). It is noteworthy that processed meats (sausage, bologna sausage and bacon) contribute more to the onset of $T 2 D$, because of their saturated fat, sodium and nitrite contents. The authors of this study believe that at least one of these compounds, used for preserving processed meats, can be converted to nitrosamines, which are toxic to the pancreatic beta cells, and so increase the risk of diabetes.

In addition to increasing the body's fat reserves, obesity contributes to the development of some conditions, such as high blood pressure, dyslipidemias, T2D and insulin resistance ${ }^{4}$. Insulin resistance involves impaired insulin signaling and/ or glucose transporter, especially isoform Glucose Transporter 4 (GLUT-4), which is found in skeletal muscle and adipose tissue, and results in hyperglycemia and sometimes in compensatory hyperinsulinemia. Insulin resistance is the pathophysiological basis of type- 2 diabetes (T2D) ${ }^{5}$.

According to the literature, obese individuals consume high-fat diets ${ }^{6,7}$. This kind of diet is 
known as cafeteria diet because of the large amount of fats present in its foods, leading to significant weight gain and insulin resistance ${ }^{8}$. There are few studies in the literature that fed rats the cafeteria diet and chow simultaneously. In general, most studies offer pellets containing a mixture of dissolved high-fat foods and standard chow $^{9-11}$. This study aimed to create an inexpensive and easily reproducible animal model of obesity using a high-fat diet consisting of common high-fat foods, that is, the cafeteria diet.

The present study verified whether fourteen weeks of the cafeteria diet could increase body weight, fat mass and skeletal muscle mass and cause insulin resistance in male Wistar rats.

\section{METHODS}

Twenty adult, male Wistar rats were randomized into two groups, Control (C) and Obese (O). Both groups had free access to water and rodent chow. Temperature, light and humidity were controlled (Mean-M=22, Standard-Error$\mathrm{SE}=2^{\circ} \mathrm{C}, 12 \mathrm{~h}$ light - dark cycle and $45 \%$ relative humidity). The experimental protocol followed the ethical principles for animal research set forth by the Brazilian College of Animal Experimentation and was approved by the local Ethics Committee for Research on Animals (Process \# 79/2009).

The obese group was given a cafeteria diet consisting of sandwich cookies, bologna sausage, sausage, bacon and a soft drink ${ }^{12,13}$. The cafeteria and standard diets were weighed before and after consumption. The daily consumption was calculated by subtracting the leftovers from the total amount of food offered per day. The cafeteria diet consisted of bacon ( $8.04 \mathrm{~g}$ of protein, $62.81 \mathrm{~g}$ of fats and $2.93 \mathrm{~g}$ of carbohydrates totaling $609 \mathrm{kcal})$, cookies $(20.03 \mathrm{~g}$ of fats and $70.39 \mathrm{~g}$ of carbohydrates totaling $487 \mathrm{kcal})$, bologna sausage (17.6g of protein, $17.18 \mathrm{~g}$ of fats and $19.09 \mathrm{~g}$ of carbohydrates totaling $301 \mathrm{kcal})$, soft drink ( $10.48 \mathrm{~g}$ of carbohydrates totaling $41.67 \mathrm{kcal})$, sausage $(10.18 \mathrm{~g}$ of protein, $22.55 \mathrm{~g}$ of fats and $5.45 \mathrm{~g}$ of carbohydrates totaling $265 \mathrm{kcal})$ and standard show ( $23 \mathrm{~g}$ of protein, $4 \mathrm{~g}$ of fats and $49 \mathrm{~g}$ of carbohydrates totaling $378 \mathrm{kcal})$. All values are for $100 \mathrm{~g}$ of food or $100 \mathrm{~mL}$ of soft drink.

The animals were weighed weekly to map weight gain over time.

In the eighth week of the intervention, the insulin tolerance of the animals was determined by the Insulin Tolerance Test (ITT) after a 6-hour fast. All rats received an intraperitoneal injection of regular insulin (1IU/kg body weight) and blood glucose was measured at baseline (before insulin injection) and after the injection at 5 minute intervals, until the thirtieth minute ${ }^{14}$.

The Lee Index was calculated by dividing the cube root of the body weight in grams by the naso-anal length in centimeters and multiplying by $100^{15,16}$.

At the end of the intervention, the animals were anesthetized intraperitoneally by sodium thiopental $(60 \mathrm{mg} / \mathrm{kg}$ body weight). When the animal's cornea and paw no longer responded to pain, a median laparotomy was done to remove the periepididymal adipose tissue and skeletal muscles soleus and Extensor Digitorum Longus (EDL). All tissues were weighed.

Table 1. Morphometric data of control and obese animals and glycemia level.

\begin{tabular}{|c|c|c|c|c|c|c|c|c|c|c|c|c|c|c|c|c|}
\hline \multirow{3}{*}{ Groups } & \multicolumn{10}{|c|}{ Morphometric Data } & \multirow{2}{*}{\multicolumn{2}{|c|}{$\begin{array}{l}\text { Index } \\
\text { of Lee }\end{array}$}} & \multirow{2}{*}{\multicolumn{2}{|c|}{$\begin{array}{l}\text { Fasting } \\
\text { Glycemia }\end{array}$}} & \multirow{2}{*}{\multicolumn{2}{|c|}{$\begin{array}{l}\text { Relation of } \\
\text { AT/BWx100 }\end{array}$}} \\
\hline & \multicolumn{2}{|c|}{$\begin{array}{c}\text { Body } \\
\text { Weight }\end{array}$} & \multicolumn{2}{|c|}{$\begin{array}{l}\text { A. Tissue } \\
\text { Weight }\end{array}$} & \multicolumn{2}{|c|}{$\begin{array}{l}\text { Soleus } \\
\text { Weight }\end{array}$} & \multicolumn{2}{|c|}{$\begin{array}{c}\text { EDL } \\
\text { Weight }\end{array}$} & \multicolumn{2}{|c|}{$\begin{array}{c}\text { Liver } \\
\text { Weight }\end{array}$} & & & & & & \\
\hline & $M$ & SE & $\mathrm{M}$ & SE & $\mathrm{M}$ & SE & $M$ & SE & $M$ & SE & $M$ & SE & $M$ & SE & $M$ & SE \\
\hline Control & 467 & 14.7 & 5.2 & 0.7 & 0.195 & 0.01 & 0.22 & 0.02 & 7.6 & 0.5 & 29.8 & 0.4 & 105.1 & 3.1 & 1.18 & 0.06 \\
\hline Obese & 528 & $24^{*}$ & 9.8 & $3.5^{* *}$ & 0.211 & 0.01 & 0.221 & 0.03 & 13.5 & $0.5 \#$ & 30.6 & $0.5^{*}$ & 126.8 & $2.5^{* *}$ & $2.4^{* *}$ & $0.24^{* *}$ \\
\hline $\mathrm{n}$ & & & & & & & & & & & 5 & 5 & & 5 & & 6 \\
\hline
\end{tabular}

Data are Mean (M) e Standard Error (SE). AT/BW (AT: Adipose Tissue, BW: Body Weight); EDL: Extensor Digitorum Longus.

${ }^{*}$ Values different significantly $(p<0.05) ;{ }^{* *}$ Values different significantly $(p<0.01)$; \# Values different significantly $(p<0.0001)$ 
316 | DAC PINTO JÚNIOR \& PM SERAPHIM

Table 2. Weekly consumption and energy intake.

\begin{tabular}{|c|c|c|c|c|c|c|c|c|c|c|c|c|c|c|c|c|}
\hline \multirow{3}{*}{ Weeks } & \multicolumn{4}{|c|}{ Control } & \multicolumn{10}{|c|}{ Obese } & \multicolumn{2}{|c|}{$\begin{array}{c}\Delta \text { between } \\
\text { Control and } \\
\text { Obese }\end{array}$} \\
\hline & \multicolumn{2}{|c|}{ Chow (g) } & \multicolumn{2}{|c|}{ Chow (kcal) } & \multicolumn{2}{|c|}{ Chow (g) } & \multicolumn{2}{|c|}{ Chow (kcal) } & \multicolumn{2}{|c|}{ Diet (g) } & \multicolumn{2}{|c|}{ Diet (kcal) } & \multirow{2}{*}{$\begin{array}{c}\text { Food } \\
(\mathrm{g})\end{array}$} & \multirow{2}{*}{$\begin{array}{l}\text { Food } \\
\text { (kcal) }\end{array}$} & \multirow{2}{*}{$\begin{array}{c}\Delta \\
(\mathrm{g})\end{array}$} & \multirow{2}{*}{$\begin{array}{c}\Delta \\
(\text { kcal })\end{array}$} \\
\hline & $M$ & SE & $M$ & SE & $M$ & SE & $M$ & SE & $M$ & SE & $M$ & SE & & & & \\
\hline 1 & 143 & 3 & 429 & 9 & 95 & $6^{* *}$ & 285 & $18^{* *}$ & 65 & 7 & 278 & 31 & 160 & 563 & -17 & -134 \\
\hline 2 & 122 & 4 & 366 & 12 & 88 & $8^{* *}$ & 264 & $36^{* *}$ & 62 & 5 & 294 & 33 & 150 & 558 & -28 & -192 \\
\hline 3 & 146 & 2 & 438 & 6 & 98 & $7^{* *}$ & 294 & $21^{* *}$ & 77 & 7 & 334 & 49 & 175 & 628 & -29 & -190 \\
\hline 4 & 176 & 15 & 528 & 45 & 58 & $6^{* *}$ & 174 & $18^{* *}$ & 87 & 8 & 347 & 55 & 145 & 521 & 31 & 7 \\
\hline 5 & 135 & 7 & 405 & 21 & 71 & $15^{* *}$ & 213 & $45^{* *}$ & 105 & 12 & 446 & 89 & 176 & 659 & -41 & -254 \\
\hline 6 & 229 & 21 & 687 & 63 & 149 & $31^{*}$ & 447 & $93^{*}$ & 81 & 11 & 282 & 27 & 230 & 729 & -1 & -42 \\
\hline 7 & 151 & 7 & 453 & 21 & 122 & 16 & 366 & 48 & 122 & 10 & 474 & 61 & 244 & 840 & -93 & -387 \\
\hline 8 & 189 & 20 & 567 & 60 & 86 & $12^{* *}$ & 258 & $36^{* *}$ & 91 & 10 & 297 & 22 & 177 & 555 & 12 & 12 \\
\hline 9 & 174 & 26 & 522 & 78 & 74 & $16^{*}$ & 222 & $48^{*}$ & 93 & 9 & 325 & 31 & 167 & 547 & 7 & -25 \\
\hline 10 & 187 & 34 & 561 & 102 & 661 & $21^{*}$ & 198 & $63^{*}$ & 101 & 11 & 370 & 47 & 167 & 568 & 20 & -7 \\
\hline 11 & 179 & 33 & 537 & 99 & 74 & $19^{*}$ & 222 & $57^{*}$ & 91 & 14 & 294 & 30 & 165 & 516 & 14 & 21 \\
\hline 12 & 185 & 36 & 555 & 108 & 70 & $18^{*}$ & 210 & $54^{*}$ & 96 & 14 & 457 & 101 & 166 & 667 & 19 & -112 \\
\hline 13 & 208 & 50 & 624 & 150 & 93 & 26 & 279 & 78 & 128 & 6 & 477 & 71 & 221 & 756 & -13 & -132 \\
\hline 14 & 239 & 30 & 717 & 90 & 85 & $16^{* *}$ & 255 & $48^{* *}$ & 125 & 21 & 614 & 167 & 210 & 869 & 29 & -152 \\
\hline
\end{tabular}

${ }^{*} p<0.05$ vs Control; ${ }^{* *} p<0.001$ vs Control; M: Mean; SE: Standard Error

Descriptive statistics was used to compare the means and the results were shown as mean e standard error. The data were treated by one-way Analysis of Variance (ANOVA) and the post-hoc test Bonferroni correction. The significance level was set at $5 \%(p<0.05)$.

\section{RE S U L T S}

Table 1 below shows the animals' morphometric profiles on the day they were killed. The two groups differed significantly in all study variables (body weight, white fat tissue weight and Lee Index).

The graph below shows the weekly weight of the animals. The animals that received the cafeteria diet became significantly heavier than the control group after two weeks of the diet (Figure 1).

The amount of chow and cafeteria diet consumed daily was monitored for estimating food intake, expressed in grams and kcal. Food intake in grams was very similar, but not in Kcal: the obese group consumed more energy than the control group. Sometimes the control group consumed more food in grams than the obese group, but the obese group always consumed more energy (Table 2).

The Insulin Tolerance Test was performed twice: eight weeks after baseline (Time 1) and right before euthanasia (Time 2). At Time 1, the behavior of the Decay Constant of Glycemia on Insulin Tolerance Test (kITT) curve (glucose decay constant represented by percentage of glucose decay per minute) of the two groups was very

Body Weight Evolution

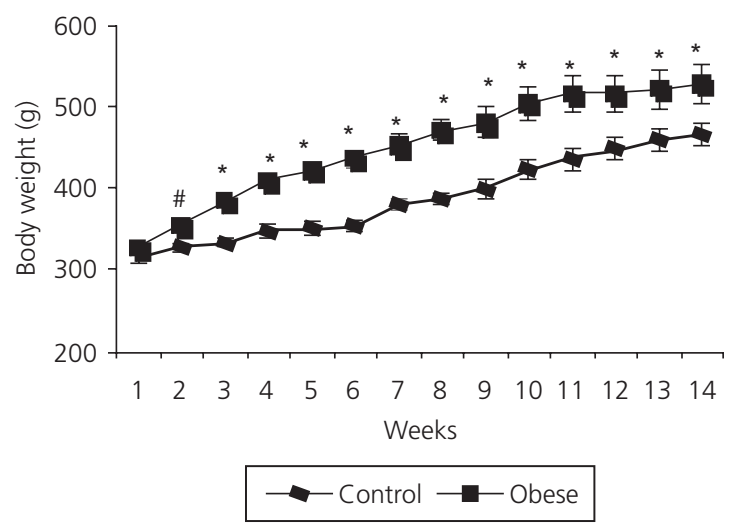

Figure 1. Body weight evolution during 14 weeks.

Note: Weight on $2^{\text {nd }}$ week: \# $p<0.05$ vs Control; Weight on $3^{\text {rd }}$ week until the end of the study: ${ }^{*} p<0.0001$ vs Control. $n=10$. 
ITT Moment 1

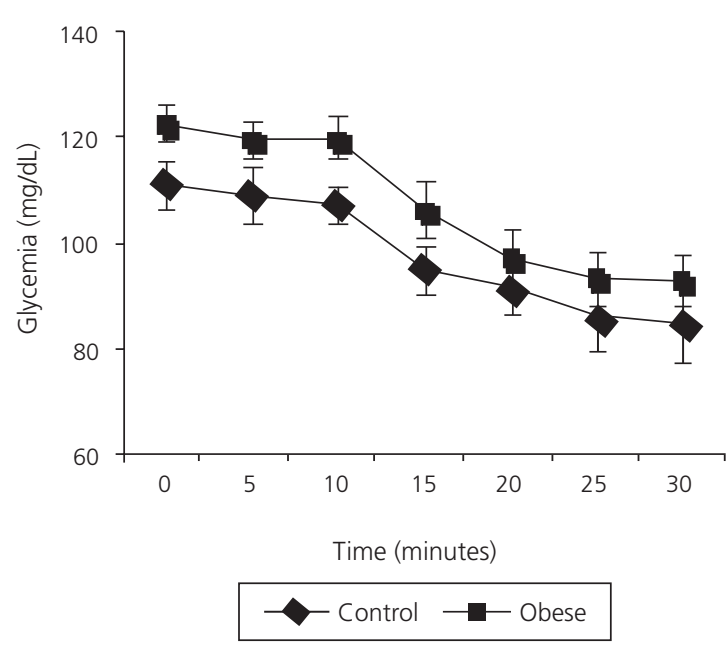

ITT Moment 2

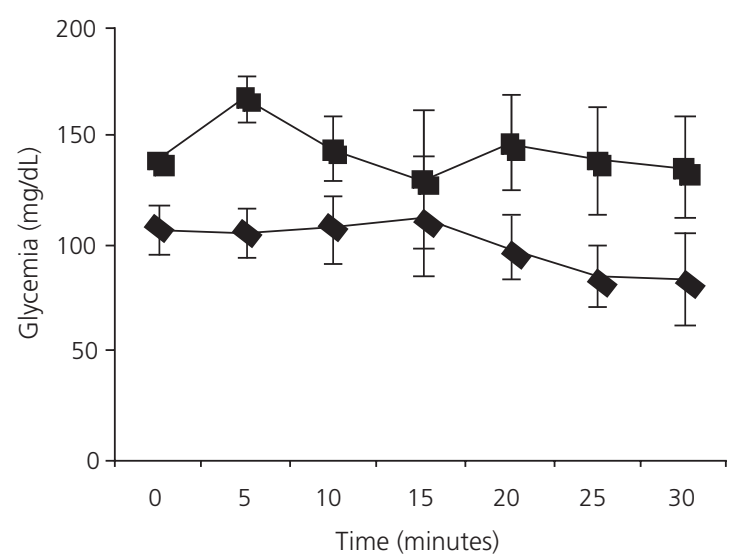

$\longrightarrow$ Control Obese

Figure 2. Insulin Test Tolerance (decay glycemia curve) in Moment 1 ( $8^{\text {th }}$ week) and in Moment 2 (before euthanasia).

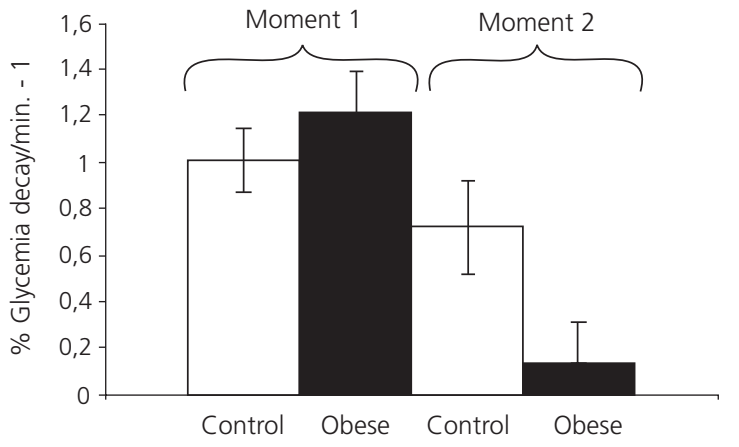

Figure 3. In $8^{\text {th }}$ week and 1 week before euthanasia animals were submitted to an insulin tolerance test, which animals received an intraperitoneal dose of human regular insulin (1 IU/Kg body weight) and the decay of glycemia was monitored every five minutes until 30 .

Note: Results were expressed in a constant decay (kITT). kITT in the $8^{\text {th }}$ week (Moment 1) and kITT before euthanasia (Moment 2): * $p<0.05$ vs Control; $n=10$.

similar. However, at Time 2, the slope of the glucose decay curve of the obese group was less steep than that of the control group (Figures 2 e 3 ).

\section{DISCUSSION}

The obese population has grown significantly because of poor food habits (junk food), inactivity and/or genetic disorders. There have been recent reports in the literature that insulin resistance is associated with subclinical inflammatory state, which is associated with proinflammatory cytokine production especially in obese or T2D individuals ${ }^{17}$.

A classical model that impairs the entire insulin signaling machinery is Insulin Receptor Substrate-1 (IRS-1) serine 307 phosphorylation ${ }^{18}$. This strongly inhibits insulin signaling because it prevents IRS-1 tyrosine kinase activity, causing a state of insulin resistance, and promotes the activity of two serine kinases, c-Jun $\mathrm{N}$ - terminal Kinase 1 (JNK1) and Inhibitor of Kappa $\beta$ (IKK) ${ }^{19,20}$.

Serine kinases in the endoplasmic reticulum can be activated by stress and reactive oxygen species ${ }^{21-24}$. Another factor directly involved in high IRS-1 serine phosphorylation is high proinflammatory cytokine levels, such as interleukin-6 (IL-6) and Tumor Necrosis Factoralpha (TNF- $\alpha$ ), because of the interaction between these cytokines and their respective receptors ${ }^{25,26}$. Toll-like receptors can be related to serine kinase activity, because they are activated by bacterial lipopolysaccharides and saturated fatty acids ${ }^{27-29}$.

The morphometric profile analysis of the present study clearly showed that the cafeteria diet affected some variables, promoting significant increase of body and white fat tissue weights and 
Lee Index, confirming the data above. Based on the relative weights, the higher body weights of the animals at the end of the diet were due to fat mass gain. Additionally, the liver was also heavier in the obese group and lighter in color, suggesting higher content of fat droplets as observed by Sampey et al. ${ }^{30}$ ten weeks after introducing a cafeteria diet, which was associated with severe hepatic inflammation.

Figure 1 shows the significant weight gain of the obese group. The graph shows the weekly weight of the animals and the different weights of the obese and Control groups, which started differing on the second week and remained until the end of the study. Table 2 explains this weight gain, as it shows food intake in grams and kcal. Sometimes the control animals consumed more food in grams than the obese group, but the energy intake was always higher in the Obese group. Rats given free access to a mixed diet (chow and cafeteria) evidently consumed less chow and liked the cafeteria food more and more over time, suggesting that fourteen weeks of cafeteria diet were not enough for the body to adapt to the energy density of the new food.

Regarding kITT assessment, the insulin sensitivity of both groups at Time 1 was similar, but at Time 2 the kITT of the Obese group had changed (Figure 3). Probably at Time 1, insulin resistance was not yet well established, corresponding to a stage where fat mass was increasing because of higher glucose uptake and quick conversion of serum glucose to fat. At Time 2 , insulin resistance was already well established and some cytokines secreted by the greater fat mass could have impaired glucose uptake by peripheral tissues, such as skeletal muscle ${ }^{31}$. This rise in blood glucose overstimulates pancreatic beta cells, making them release more insulin (compensatory hyperinsulinemia), but the effect

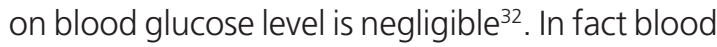
glucose levels in the obese animals increased, corroborating the ITT results. However, serum TNF- $\alpha$ was undetectable in all groups (data not shown), suggesting absence of inflammatory state.

In conclusion, fourteen weeks of a cafeteria diet consisting of sausage, bologna sausage, bacon, sandwich cookies and soda was enough to make the animals obese and significantly decrease insulin sensitivity. This is a great and inexpensive animal model of diet-induced insulin resistance.

\section{ACKNOWLEDGMENTS}

Danilo Antonio Corrêa Pinto Junior received a grant from Fundação de Amparo à Pesquisa do Estado de São Paulo (proc \# 2009/13475-1).

\section{CONTRIBUTIONS}

DAC PINTO JÚNIOR performed all the treatment of animals and wrote the manuscript. PM SERAPHIM tutor, analyzed the results and wrote the manuscript.

\section{REFERE N CES}

1. World Healthy Organization. Obesity and overweight. Geneva: WHO; 2012.

2. Damaso A, Guerra RLF, Botero JP, Prado WL. Etiologia da obesidade. In: Damaso A. Obesidade. Rio de Janeiro: Medsi; 2003.

3. Pan A, Sun Q, Bernstein AM, Schulze MB, Manson $J E$, Willett WC, et al. Red meat consumption and risk of type 2 diabetes: 3 cohorts of US adults and an updated metaanalysis. Am J Clin Nutr. 2011; 94:1-9.

4. Machado UF, Schaan BD, Seraphim PM. Glucose transporters in the metabolic syndrome. Arq Bras Endocrinol Metab. 2006; 50(2):177-89.

5. Rizvi AA. Hypertension, obesity and inflammation: the complex designs of a deadly trio. Metab Syndr Relat Disord. 2010; 8(4):287-94.

6. Blundell JE, Gillet A. Control of food intake in the obese. Obes Res. 2001; 9(4):263S-70S.

7. De Souza CT, Araújo EP, Bordin S, Ashimine R, Zollner R, Boschero AC, et al. Consumption of a fat: rich diet activates a proinflammatory response and induces insulin resistance in the hypothalamus. Endocrinology. 2005; 146(10):4192-9.

8. Bertrand RL, Senadheera S, Markus I, Liu L, Howitt $\mathrm{L}$, Chen $\mathrm{H}$, et al. A Western diet increases serotonin availability in rat small intestine. Endocrinology. 2011; 152(1):36-47.

9. Ghitza UE, Nair SG, Golden SA, Gray SM, Uejima $\mathrm{JL}$, Bossert JM, et al. Peptide YY3-36 decrases reinstatement of high-fat-food seeking during dieting in a rat relapse model. J Neurosci. 2007; 27(43):11522-32. 
10. Scoaris CR, Rizo GV, Roldi LP, De Moraes SMF, De Proença ARG, Peralta RM, et al. Effects of cafeteria diet on the jejunum in sedentary and physically trained rats. Nutrition. 2010; 26(3):312-20.

11. Brunetti L, Leone S, Orlando G, Recinella L, Ferrante C, Chiavaroli A, et al. Effects of obestatin on feeding and body weight after standard or cafeteria diet in the rat. Peptides. 2009; 30(7):1323-7.

12. Lamas O, Martinez JA, Marti A. Energy restriction restores the the impaired immune response in overweight (cafeteria) rats. J Nutr Biochem. 2004; 15(7):418-25.

13. Ribot J, Rodríguez AM, Rodríguez E, Palou A. Adiponectin and resistin response in the onset of obesity in male and female rats. Obesity. 2008; 16(4):723-30.

14. Padua MF, Padua TF, Pauli JR, Souza CT, Silva ASR, Ropelle ECC, et al. Physical exercise decreases fasting hyperglycemia in diabetic mice through AMPK activation. Rev Bras Med Esporte. 2009; 15(3):179-84.

15. Bernardis LL, Patterson BD. Correlation between "Lee Index" and carcass fat content in weanling and adult female rats with hypothalamic lesions. J Endocrinol. 1968; 40(4):527-8.

16. Araújo GG, Araújo MB, Dangelo RA, ManchadoGobatto FB, Mota CSA, Ribeiro C, et al. Maximal Lactate stead state in obese rats of both genders. Rev Bras Med Esporte. 2009; 15(1):46-9.

17. De Carvalho MHC, Colaço AL, Fortes ZB. Citokines, endothelial dysfunction and insulin resistance. Arq Bras Endocrinol Metab. 2006; 50(2):304-12.

18. Hotamisligil GS, Peraldi P, Budavari A, Ellis R, White MF, Spiegelman BM. IRS - 1 mediated inhibition of insulin receptor tyrosine kinase activity in TNF - alpha and obesity - induced insulin resistance. Science. 1996; 271(5249):665-8.

19. Prada PO, Zecchin HG, Gasparetti AL, Torsoni MA, Ueno $M$, Hirata $A E$, et al. Western Diet modulates insulin signaling, c - Jun N - Terminal Kinase activity,

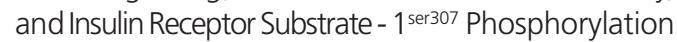
in a Tissue - Specific Fashion. Endocrinology. 2005; 146(3):1576-87.

20. Sabio G, Davis R. cJUN NH2 - terminal kinase 1 (JNK1): roles in metabolic regulation of insulin resistance. Trends Biochem Sci. 2010; 35:490-6.

21. Kaneto H, Nakatani Y, Kawamori D, Miyatsuka T, Matsuoka TA, Matsuhisa M, et al. Role of oxidative stress, endoplasmic reticulum stress, and c - Jun N Terminal kinase in pancreatic $\beta$ - cell dysfunction and insulin resistance. Int J Biochem Cell Biol. 2006; 38(5-6):782-93.

22. Nakatani $Y$, Kaneto $H$, Kawatomi $Y$, Hatazaki $M$, Matsuoka T, Ozawa K, et al. Involvement of endoplasmic reticulum stress in insulin resistance and diabetes. J Biol Chem. 2005; 280(1):847-51.

23. Ozawa K, Mayuki M, Munehide M, Katsura T, Yoshihisa N, Masahiro $\mathrm{H}$, et al. The endoplasmic reticulum chaperone improves insulin resistance in type 2 diabetes. Diabetes. 2005; 54(3):657-63.

24. Hotamisligil GS. Role of endoplasmic reticulum stress and c - Jun NH2 - terminal kinase pathways in inflammation and origin of obesity and diabetes. Diabetes. 2005; 54(2):S73-S78.

25. Tanti JF, Jager J. Cellular mechanisms of insulin resistance: role of stress - regulated serine kinase and insulin receptor substrates (IRS) serine phosphorylation. Curr Opin Pharmacol. 2009; 9(6): 753-62.

26. Shoelson SE, Lee J, Goldfine AB. Inflammation and insulin resistance. J Clin Invest. 2006; 116(7): 1793-801.

27. Ray M, Yu S, Sharda DR, Wilson CB, liu Q, Kaushal $N$, et al. Inhibition of TLR4: Induced by IKB kinase activity by the RON receptor tyrosine kinase and its ligand, macrophage - stimulating protein. J Immun. 2010; 185(12):7309-16.

28. Lee JY, Sohn KH, Rhee SH, Hwang D. Saturated fatty acids, but not unsaturated fatty acids, induce the expression of cyclooxygenase: 2 mediated through Toll - like receptor 4. J Biol Chem. 2001; 276(20):16683-9.

29. Kim F, Pham M, Luttrell I, Bannerman DD, Tupper J, Thaler J, et al. Toll: like receptor - 4 mediates vascular inflammation and insulin resistance in diet - induced obesity. Circ Res. 2007; 100(11): 1589-96.

30. Sampey BP, Vanhoose AM, Winfield HM, Freemerman AJ, Muehlbauer MJ, Fueger PT, et al. Cafeteria diet is a robust model of human metabolic syndrome with liver and adipose inflammation: comparison to high: fat feed. Obesity. 2011; 19(6): 1109-17.

31. Costa $A C P$, Pinto Jr DAC, Brandão BB, Moreira RJ, Machado UF, Seraphim PM. Resistive training reduces inflammation in skeletal muscle and improves the peripheral insulin sensitivity in obese rats induced by hyperlipidic diet. Arq Bras Endocrinol Metab. 2011; 55(2):155-63.

32. Miyake K, Ogawa W, Matsumoto M, Nakamura T, Sakaue $H$, Kasuga M. Hyperinsulinemia, glucose intolerance, and dyslipidemia induced by acute inhibition of phosphoinositide 3: kinase signaling in the liver. J Clin Invest. 2002; 110(10):1483-91.

Received on: 30/11/2011 Final version on: 4/5/2012 Approved on: 16/5/2012 
